SOCIAL SECURITY: PRIVATIZATION AND PROGRESSIVITY

\author{
Laurence J. Kotlikoff \\ Kent A. Smetters \\ Jan Walliser
}

Working Paper 6428 
NBER WORKING PAPER SERIES

\title{
SOCIAL SECURITY: PRIVATIZATION AND PROGRESSIVITY
}

\author{
Laurence J. Kotlikoff \\ Kent A. Smetters \\ Jan Walliser
}

Working Paper 6428

http://www.nber.org/papers/w6428

\section{NATIONAL BUREAU OF ECONOMIC RESEARCH \\ 1050 Massachusetts Avenue \\ Cambridge, MA 02138 \\ February 1998}

Any opinions expressed are those of the authors and not those of the Congressional Budget Office or the National Bureau of Economic Research.

(c) 1998 by Laurence J. Kotlikoff, Kent A. Smetters and Jan Walliser. All rights reserved. Short sections of text, not to exceed two paragraphs, may be quoted without explicit permission provided that full credit, including (C) notice, is given to the source. 
Social Security: Privatization and Progressivity

Laurence J. Kotlikoff, Kent A. Smetters

and Jan Walliser

NBER Working Paper No. 6428

February 1998

JEL No. H55

\section{ABSTRACT}

This paper uses a large-scale overlapping generations model that features intragenerational heterogeneity to show that privatizing the U.S. Social Security System could be done on a progressive basis. We start with a close replica of the current system; specifically, we include Social Security's progressive benefit schedule together with its exact age-specific marginal linkages between taxes paid and benefits received.

The paper compares achieving progressivity as part of privatization reform by a) providing a pay-as-you-go-financed minimum benefit to all agents at retirement independent of their contributions and $b$ ) matching contributions to private retirement accounts on a progressive basis.

Although a pay-as-you-go-financed minimum benefit can enhance progressivity, it comes at the cost of substantially smaller long-run macroeconomic and welfare gains. The reasons are two: First, the ongoing unfunded liability to pay for the minimum benefit is roughly half of the unfunded liability of the current Social Security system. Maintaining this liability limits the effect of privatization on saving and capital accumulation. Second, the tax financing the flat minimum benefit is completely distortionary since the benefit one receives is independent of what one contributes.

In contrast, matching worker's contributions on a progressive basis can achieve an equally progressive intragenerational distribution of welfare. But it affords much higher long-run levels of capital, labor supply, output and welfare.

\author{
Laurence J. Kotlikoff \\ Department of Economics \\ Boston University \\ Boston, MA 02215 \\ and NBER \\ kotlikof@bu.edu
}

Jan Walliser

Congressional Budget Office

House Annex 2, SW

Washington, DC 20515

janw@cbo.gov

\author{
Kent A. Smetters \\ Congressional Budget Office \\ House Annex 2, SW \\ Washington, DC 20515 \\ kents@cbo.gov
}




\section{Introduction}

The Balanced Budget Agreement of 1997 achieved budgetary balance by the year 2002 but did not resolve the nation's long-term fiscal problems. Those problems stem, in large part, from the Medicare and Social Security programs whose projected expenditures outstrip their projected receipts. One government commission is now addressing Medicare's finances. Another -- the Social Security Advisory Council -- recently delivered three mutually exclusive sets of recommendations, one of which calls for the system's privatization.

A sizeable literature shows that privatizing Social Security would increase the economy's long-run productive capacity at the price of higher fiscal burdens for those generations alive during the transition. ${ }^{1}$ Less well studied is how Social Security's privatization would alter the intragenerational resource distribution. The answer, as discussed below, depends on the method of privatization. Some privatization schemes entail no progressive elements. But even these schemes may help the long-run poor more than the long-run rich. Other schemes use flat minimum benefits or progressive contribution matches to enhance intragenerational progressivity.

This paper studies the interface of Social Security privatization and progressivity using a large-scale overlapping generations model. The model includes Social Security's progressive benefit schedule and calculates the marginal link between taxes and benefits for each age and income level. The paper's bottom line is that privatization and progressivity can be mutually compatible, particularly if the redistribution is achieved through progressive matching of individual accounts and is financed with a consumption tax.

1 The literature includes Feldstein and Samwick (1998), Raffelhuschen (1993), Arrau and Schmidt-Hebbel (1993), Kotlikoff (1996), Kotlikoff, Smetters, and Walliser (1997). 


\section{The Model}

Our model (Altig et. al., 1997, Kotlikoff, Smetters, and Walliser, 1997) is a substantially enhanced version of the Auerbach-Kotlikoff (1987) dynamic general equilibrium model. It features 55 overlapping generations and solves for the economy's perfect-foresight transition path. The model, which is calibrated to U.S. data, has three sectors: households, firms, and the government. Households allocate their full lifetime resources to consumption and leisure over their life span (ages 21 to 75 ); retirement decisions are endogenous. Household behavior is governed by a time-separable CES utility function with intertemporal and intratemporal elasticities of substitution of 0.25 and 0.8 , respectively. Population and productivity both grow at 1 percent per year.

The model follows Fullerton and Rogers (1993) in capturing intragenerational heterogeneity by dividing each cohort into 12 lifetime-earnings classes. The 12 classes represent the 10 deciles of the population ranked by lifetime income where the bottom and top decile are each divided into percentiles of 2 and 8 percent. Age-productivity profiles for each of these classes were estimated from the Panel Study of Income Dynamics. ${ }^{2}$ Firms are perfectly competitive and maximize profits subject to a Cobb-Douglas production function with a capital-income share of 25 percent.

The government collects taxes to finance government consumption and OASDHI benefits. In the initial steady state, the U.S. tax system is represented by a proportional state and federal consumption tax, a proportional state income tax, a proportional federal capital income tax, a proportional federal payroll tax with an earnings ceiling, and a progressive federal wage tax with a standard deduction. The proportional capital income tax and the progressive wage tax approximate

\footnotetext{
2 For a detailed description of the estimation see the Appendix of Altig et al. (1997).
} 
the federal income tax. ${ }^{3}$ Thus, household's budget constraints are non-convex and non-differentiable because of the payroll tax ceiling and the wage deduction. We employ a search routine at non-convex areas and assign virtual marginal tax rates to solve for household leisure and consumption choices at non-differentiable points.

The model's initial steady-state OASI payroll tax rate is 9.9 percent. The total payroll tax rate including Hospital Insurance (HI) and Disability Insurance (DI) is 14.7 percent. HI benefits are modeled as a constant transfer to agents of age 65 and over and DI benefits are modeled as a constant transfer to agents below age 65 .

The model applies Social Security's OASI inflation-indexed benefit formula to each agent's average indexed earnings. Because about 50 percent of Social Security benefits are paid to survivors and spouses, we multiply benefits by a factor of two. All workers are covered by Social Security and all correctly perceive and correctly value the marginal OASI benefits they receive when they earn an extra dollar. The model solves numerically for the change in the present value of benefits generated by an extra dollar of income at each age and for each income class in each generation and the marginal link is updated in each iteration. The resulting effective marginal tax rates are displayed in Figure 1. Note that these effective tax rates are close to the 9.9 percent statutory rate at young ages, since the marginal benefits one receives for these tax payments are far off in the future and have a small present value. ${ }^{4}$ At older ages, the effective tax rates are substantially smaller. Indeed, they are negative for the lowest income-class (class 1). For the highest income-class, the effective tax rates

3 Altig et al. (1997) describe the calibration to the U.S. tax system in detail.

4 Note that those with labor income above the payroll tax ceiling (class 12) face a marginal payroll tax of zero. 
are zero in youth in middle age. For this class of agents, wage rates are so high that they earn above Social Security's maximum taxable earnings level. But in old age, when labor supply declines, earnings for this class fall below the maximum taxable level and they too confront a positive effective payroll tax rate.

Although our model incorporates many complex aspects of the economy, it ignores Social Security's role in inter- and intragenerational risk pooling. ${ }^{5}$ At first glance, one might think that a minimum benefit would provide better intragenerational insurance against poor portfolio performance of privatized individual accounts than would a system of matching contributions. Workers within a cohort whose portfolios preform poorly would find a floor under their retirement benefits. Their fellow cohort members whose portfolios preform well would find their total old-age resources (including the minimum benefit) rising by a smaller percentage than if they had been able to invest the taxes they paid to support the minimum benefit. But this presumes that workers would be free to invest their accounts in assets of their own choosing. If, for example, all workers were compelled to invest in a single global index fund, there would be no intragenerational heterogeneity in rates of return on privatized individual investment accounts.

\section{Privatizing Social Security}

Privatizing Social Security involves three elements: a) forcing workers to contribute to personal accounts, b) honoring accrued benefits, and c) choosing a method to finance accrued benefits earnings and longevity uncertainty. Walliser (1997) discusses the impact of privatization on annuities markets. 
in the transition. ${ }^{6}$ Since agents in our model are free to borrow against mandatory accounts, there is no need to add a private pension system. Instead, privatization is achieved by simply eliminating the OASI payroll tax and phasing out OASI benefits starting 10 years after the reform begins. The 10-year wait to reduce benefits, allows existing retirees to receive full benefits. After the 10th postreform year, benefits are reduced by 2.2 percent (of the original benefits) per year for the next 45 years. This gradual phase-out of benefits captures the provision of accrued benefits to existing workers.

Three alternative tax regimes - a payroll tax, an income tax, and a consumption tax -- are used to finance accrued OASI benefits. In each simulation, federal wage and capital income taxes are adjusted endogenously to balance the federal budget. Specifically, these taxes are adjusted so that the average tax rate on wage income changes by the same percentage as those on capital income. Other adjustments of the tax schedule that would make privatization more progressive could be considered.

The top panel of Table 1 shows how privatization alters macroeconomic variables. All three simulations produce the same long-run steady state. Compared to the initial steady state, the long-run steady state features a 39 percent larger capital stock, a 5 percent larger supply of labor, and a 13 percent larger level of output. The wage rate increases by 7 percent and interest rates fall almost 19 percent in response to privatization.

However, important differences exist in the speed of the transition. Financing the transition with a payroll tax reduces aggregate labor supply initially because privatization removes the link

6 We do not address the actuarial value of performance guarantees. Those guarantees may create large unfunded liabilitieswhen rates of return are uncertain (Smetters, 1997). 
between taxes and benefits for young workers. Thus, output is slightly lower in the first decade. Using income-tax finance reduces both labor supply and capital accumulation in the short run, further reducing the speed of transition. A transition financed by a consumption tax, on the other hand, can encourage savings and labor supply by taxing existing non-Social Security wealth, leading to growth even in the short to medium term.

The long-run ouput effects and the speed of transition depend on our assumption that workers understand the link between payroll taxes and benefits at the margin. If the marginal link is ill understood the payroll tax is more distortionary than in the experiments presented here, leading to a larger short-run and long-run labor supply response (see Kotlikoff, Smetters, and Walliser, 1997).

Privatization would also increase the welfare of future generations, with largest gains accruing to the average worker (see the first panel of Table 2). Utility, measured in wealth equivalents, would rise by 8 percent for average earners, 6 percent for the poorest agents, and 4.4 percent for the richest agents. While the poor benefit from reduced payroll taxes, their welfare is not affected by the growth-induced fall in income tax rates because their earnings are exempt from taxation. Higher earners benefit less than average earners because most of their earnings are above the payroll tax ceiling.

Welfare effects for generations alive during the transition depend heavily on the method of transition finance. Payroll-tax finance would harm those with the largest payroll tax burden as a percent of income -- the lifetime poorest. The elderly are largely unaffected while workers carry most of the load. Income-tax finance would put the largest burden on high earners whose capped payroll taxes are replaced by a progressive wage tax and a proportional capital income tax. Consumption taxes would levy a tax on owners of non-Social Security wealth, placing a higher burden on older and 
middle-aged generations than payroll-tax finance. Consumption taxes place a burden on the poor that is similar to payroll taxes.

\section{Privatizing with a Flat Minimum Benefit}

Some plans -- most prominently the Personal Security Account Plan of the Social Security Advisory Council -- propose a pay-as-you-go-financed flat minimum benefit. We investigate the effects of such a policy by a) providing a wage-indexed flat minimum annual benefit of $\$ 6000$ in the long run and $b$ ) paying a weighted average of the old OASI and the new flat minimum benefit during the transition. We again consider the three financing mechanisms, but now assume that these alternative taxes also finance the flat minimum benefit. In this case, the different financing methods imply different steady states.

Providing a flat minimum benefit substantially reduces the output effect of privatization (see the second panel in Table 1). Long-run increases in capital, labor and output are between 40 percent (consumption-tax finance) and 70 percent (income-tax finance) smaller than under complete privatization, also reducing the long run growth in wage rates and the reduction in interest rates. Short-run effects on capital, labor, and output are similar to complete privatization, but are substantially diminished by year 25 .

There are two reasons for these outcomes. First, the continuing unfunded liability, which amounts to about half of the unfunded liability in the current Social Security system, reduces the effect of privatization on saving and capital accumulation. Second, the tax that finances the flat minimum benefit is now completely distortionary since benefits no longer change at the margin.

The long-run welfare gains, though much smaller, are more progressive than those under 
complete privatization, particularly with income-tax financing. Welfare gains now typically range between 4 and 5 percent for most income classes, with much smaller gains accruing to top earners. Also, because the implicit debt is only reduced by half, welfare losses during the transition tend to be smaller than under full privatization.

\section{Privatizing with Progressive Matching}

Our final set of experiments considers matching contributions to mandatory private saving accounts in a progressive way. The government's match is calculated as a function of labor income and it falls steadily as a percentage of earnings, starting at about 5 percent for the poorest. In absolute terms, it increases from about $\$ 470$ at annual earnings of $\$ 10,000$ to around $\$ 840$ for annual earnings of $\$ 21,000$ and stays constant thereafter (see Figure 2). On a life-time basis, the match provides a transfer to the poorest that exceeds the flat minimum benefit of the previous section by 30 percent. Workers fully incorporate the marginal subsidy associated with the progressive contribution match into their decisions.

The first two runs reported in the third panels of Tables 1 and 2 finance the revenue shortfall from the tax credit by raising income taxes, and the third run raises consumption taxes. OASI benefits are phased out as above and financed with either a payroll tax, an income tax, or a consumption tax.

Progressive matching has a much less detrimental effect on growth than does a flat minimum benefit. The negative effects of increased income-tax rates (runs with payroll and income tax finance) or consumption-tax rates are substantially smaller than with a flat minimum benefit. However, since the government must finance all accrued benefits and the matching contribution during the early years, 
the transition with payroll-tax finance and income-tax finance is slower than in runs without matching. That slowdown is largely caused by the negative impact on aggregate labor supply due to initially higher progressive income taxes (runs with payroll and income tax finance) and the income effect from the matching of labor income. With consumption-tax finance of the matched contribution as well as accrued benefits, the transition path to the final steady state as well as to the final steady state itself is quite similar to that without the match.

The progressive matching of labor income leads to about the same percentage increase in welfare for low earners and average earners in the long run. Both groups fare as well as mean earners under complete privatization without matching. The lifetime richest, however, lose due to the progressivity of the match. Generations alive during the transition face a higher burden than under the flat minimum-benefit run, however, the lifetime poorest are better off than under privatization without matching.

\section{Conclusions}

Privatization can offer substantial long-run economic gains. But those gains aren't free, nor are they immediate. Some transition generations face higher fiscal burdens, and depending on how the transition is financed, it can be quite slow.

Enhancing progressivity in a privatized system with a pay-go-financed flat minimum benefit comes at the cost of substantially smaller long-run macroeconomic and welfare gains. Matching worker's contributions on a progressive basis is an alternative means of making Social Security's privatization more progressive. Compared to using a flat minimum benefit, this policy achieves an equally progressive long-run distribution of welfare. But it affords much larger long-run levels of 
capital, labor supply, output, and welfare. 


\section{References}

Altig, David, Auerbach, Alan J., Kotlikoff, Laurence J., Smetters, Kent A., and Walliser, Jan. "Simulating U.S. Tax Reform." National Bureau of Economic Research (Cambridge, MA), Working Paper No. 6248, October 1997.

Arrau, Patricio and Schmidt-Hebbel, Klaus. "Macroeconomic and Intergenerational Welfare Effects of aTransition from Pay-as-You-Go to Fully Funded Pensions." Policy Research Department Working Paper, World Bank (Washington, D.C.), 1993.

Auerbach, Alan J. and Kotlikoff, Laurence J. Dynamic Fiscal Policy. Cambridge: Cambridge University Press, 1987.

Bohn Henning. "Social Security Reform and Financial Markets." Mimeo, University of California at Santa Barbara, 1997.

Feldstein, Martin S. and Samwick, Andrew A. "The Transition Path in Privatizing Social Security, in Martin S. Feldstein, ed., Privatizing Social Security. Chicago: University of Chicago Press, 1998.

Fullerton, Don and Rogers, Diane Lim. Who Bears the Lifetime Tax Burden? Washington, D.C.: The Brookings Institution, 1993.

Huang, He, Imrohoroglu, Selo and Sargent, Thomas."Two Computational Experiments to Fund Social Security." forthcoming in Macroeconomic Dynamics.

Kotlikoff, Laurence J. "Privatizing Social Security: How It Works and Why It Matters," in James M. Poterba, ed.,Tax Policy and the Economy 10, Cambridge, Mass.: MIT Press, 1996.

Kotlikoff, Laurence J., Smetters, Kent A. and Walliser, Jan. "Opting Out of Social Security." National Bureau of Economic Research (Cambridge, MA), Working Paper, January 1998. 
Raffelhüschen, Bernd. "Funding Social Security Through Pareto-Optimal Conversion Policies." Journal of Economics/Zeitschrift für Nationalökonomie, 1993, Supplement 7, pp.105-131.

Smetters, Kent A. "Privatizing Social Security in the Presence of a Performance Guarantee." Mimeo, Congressional Budget Office, January 1998.

Walliser, Jan. "Understanding Adverse Selection in the Annuities Market and the Impact of Privatizing Social Security." CBO Technical Paper No. 1997-4, August 1997. 
Figure 1

Effective Marginal Social Security Tax Rates by Age and Income Class

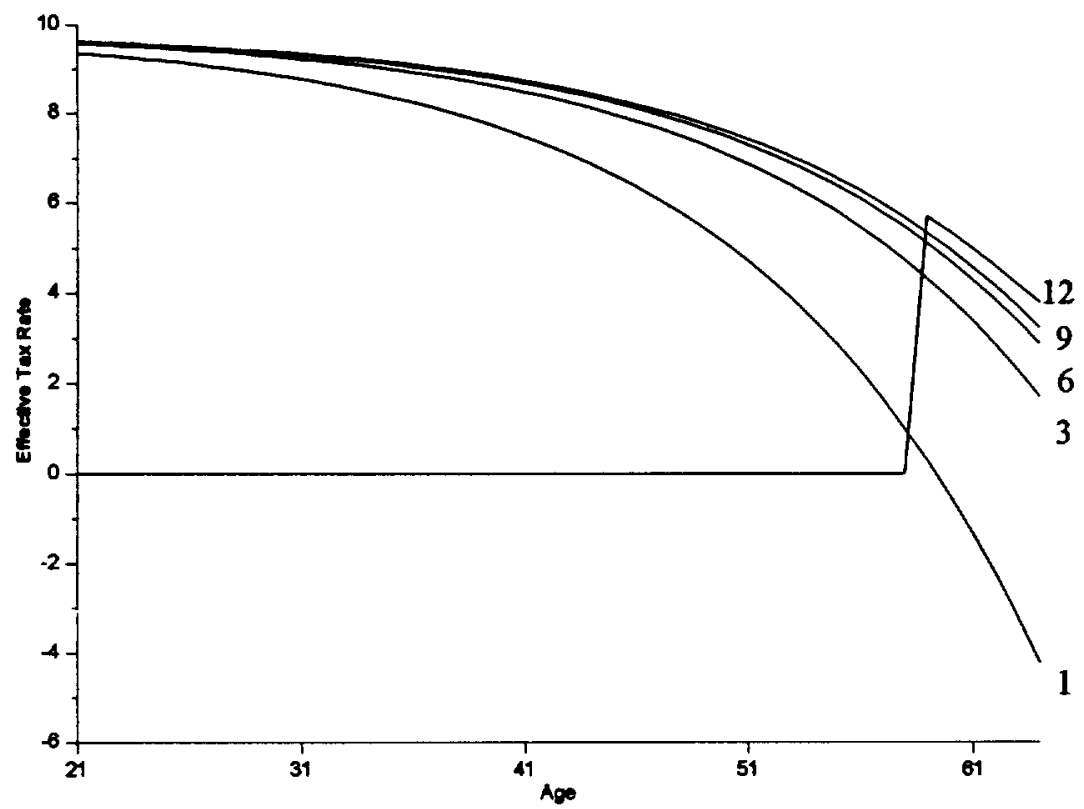


Figure 2

Matching Function

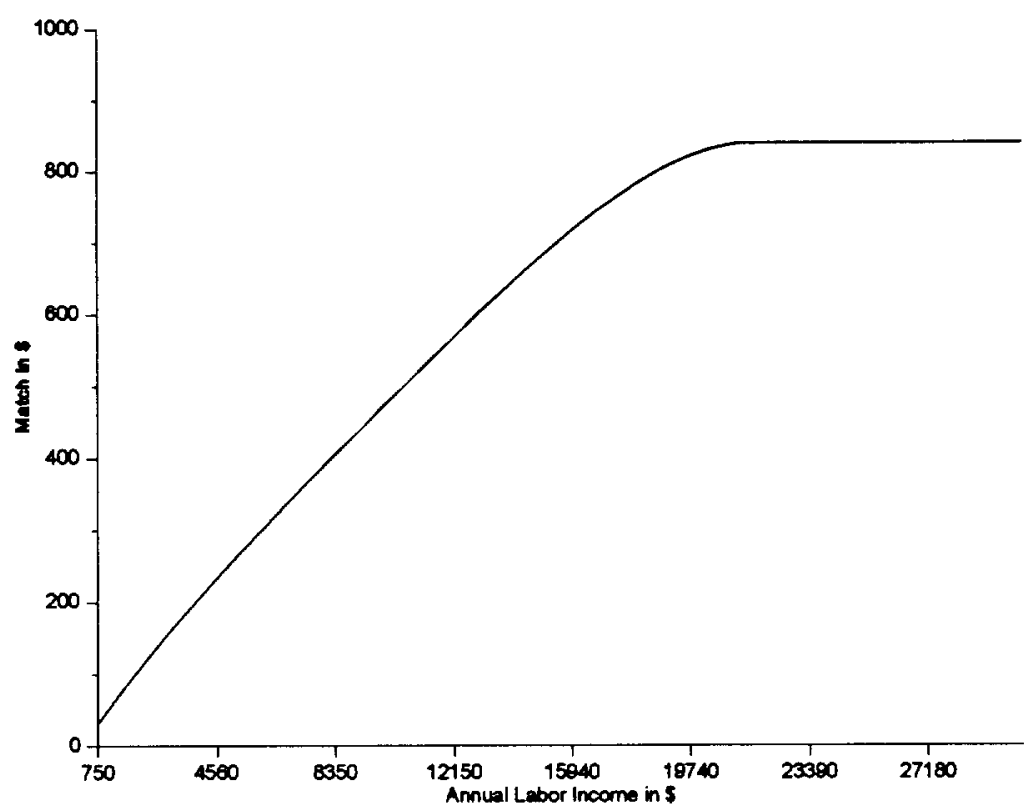


Table 1: Macroeconomic Responses to Privatization

(Percentage Change from Steady State)

Year of Transition

\begin{tabular}{|c|c|c|c|c|c|}
\hline \multirow[b]{2}{*}{ Finance } & \multirow[b]{2}{*}{ Variable } & \\
\hline & & 5 & 10 & 25 & 150 \\
\hline \multicolumn{6}{|c|}{ Privatization } \\
\hline Payroll & K & 0.3 & 0.7 & 5.2 & 38.6 \\
\hline \multirow[t]{2}{*}{ Tax } & $\mathrm{L}$ & -1.1 & -1.1 & 1.8 & 5.2 \\
\hline & $\mathrm{Y}$ & -0.8 & -0.7 & 2.6 & 12.7 \\
\hline \multirow[t]{2}{*}{-- } & w & 0.3 & 0.5 & 0.8 & 7.1 \\
\hline & $\mathrm{r}$ & -1.0 & -1.4 & -2.4 & -18.7 \\
\hline Income & K & -2.4 & -5.0 & -4.6 & 38.6 \\
\hline \multirow[t]{4}{*}{ Tax } & $\mathrm{L}$ & -4.5 & -4.7 & 0.0 & 5.2 \\
\hline & $\mathrm{Y}$ & -4.0 & -4.8 & -1.0 & 12.7 \\
\hline & w & 0.5 & 0.0 & -1.0 & 7.1 \\
\hline & $\mathrm{r}$ & -1.4 & 0.2 & 3.2 & -18.7 \\
\hline Consumption & $\mathbf{K}$ & 1.8 & 4.1 & 12.8 & 38.6 \\
\hline \multirow[t]{4}{*}{ Tax } & L & 0.3 & 0.4 & 2.4 & 5.2 \\
\hline & $\mathrm{Y}$ & 0.6 & 1.3 & 4.9 & 12.7 \\
\hline & w & 0.4 & 0.9 & 2.4 & 7.1 \\
\hline & $r$ & -11 & -27 & -69 & -187 \\
\hline
\end{tabular}

Privatization with Flat Minimum Benefit

\begin{tabular}{llrrrr}
\hline Payroll & K & 0.0 & 0.0 & 2.0 & 19.0 \\
Tax & $\mathrm{L}$ & -1.3 & -1.4 & 0.2 & 2.3 \\
& $\mathrm{Y}$ & -1.0 & -1.1 & 0.6 & 6.2 \\
& $\mathrm{w}$ & 0.3 & 0.4 & 0.5 & 3.9 \\
& $\mathrm{r}$ & -0.9 & -1.0 & -1.4 & -10.8 \\
\hline Income & $\mathrm{K}$ & -2.8 & -5.7 & -8.7 & 12.4 \\
Tax & $\mathrm{L}$ & -4.7 & -4.9 & -2.9 & 1.2 \\
& $\mathrm{Y}$ & -4.2 & -5.1 & -4.4 & 3.9 \\
& $\mathrm{w}$ & 0.5 & -0.2 & -1.5 & 2.7 \\
& $\mathrm{r}$ & -1.4 & 0.6 & 4.7 & -7.6 \\
\hline Consumption & $\mathrm{K}$ & 1.4 & 3.2 & 8.9 & 23.2 \\
Tax & $\mathrm{L}$ & 0.0 & 0.1 & 1.1 & 2.7 \\
& $\mathrm{Y}$ & 0.4 & 0.8 & 3.0 & 7.5 \\
& $\mathrm{w}$ & 0.3 & 0.8 & 1.9 & 4.7 \\
& $\mathrm{r}$ & -10 & -2.2 & -5.4 & -12.8 \\
\hline \hline
\end{tabular}


(Table 1 continued)

\begin{tabular}{lcrrrr}
\hline \multicolumn{6}{c}{ Privatization with Progressive Matching } \\
\hline Payroll & $\mathrm{K}$ & -0.7 & -1.4 & 0.9 & 35.4 \\
Tax & $\mathrm{L}$ & -3.2 & -3.3 & -0.2 & 4.0 \\
& $\mathrm{Y}$ & -2.6 & -2.9 & 0.1 & 11.1 \\
& $\mathrm{w}$ & 0.6 & 0.5 & 0.3 & 6.8 \\
& $\mathrm{r}$ & -1.9 & -1.5 & -0.8 & -17.9 \\
\hline Income & $\mathrm{K}$ & -3.4 & -7.1 & -9.7 & 35.4 \\
Tax & $\mathrm{L}$ & -6.7 & -7.3 & -3.0 & 4.0 \\
& $\mathrm{Y}$ & -5.9 & -7.2 & -4.7 & 11.1 \\
& $\mathrm{w}$ & 0.9 & 0.1 & -1.8 & 6.8 \\
& $\mathrm{r}$ & -2.6 & -0.2 & 5.4 & -17.9 \\
\hline Consumption & $\mathrm{K}$ & 1.8 & 4.1 & 13.0 & 39.8 \\
Tax & $\mathrm{L}$ & -0.5 & -0.4 & 1.7 & 4.5 \\
& $\mathrm{Y}$ & 0.0 & 0.7 & 4.4 & 12.4 \\
& $\mathrm{w}$ & 0.6 & 1.1 & 2.7 & 7.5 \\
& $\mathrm{r}$ & -17 & -3.4 & -76 & -196 \\
\hline \hline
\end{tabular}

Notes: K: Capital Stock, L: Labor Supply, Y: Output, w: wage rate, $r$ : interest rate, all runs assume positive marginal link between taxes and benefits. 
Table 2: Changes in Remaining Lifetime Utility (Wealth Equivalents)

(Percentage Change from Steady State)

Year of Birth

\begin{tabular}{|c|c|c|c|c|c|c|c|c|}
\hline \multirow[b]{2}{*}{ Finance } & \multirow[b]{2}{*}{ Class } & \\
\hline & & -54 & -25 & -10 & 1 & 10 & 25 & 150 \\
\hline \multicolumn{9}{|c|}{ Privatization } \\
\hline Payroll & 1 & 0.0 & -2.0 & -1.2 & -0.6 & 0.1 & 2.2 & 6.0 \\
\hline \multirow[t]{4}{*}{$\operatorname{Tax}$} & 3 & 0.0 & -1.7 & -1.1 & -0.4 & 0.5 & 3.0 & 7.3 \\
\hline & 6 & -0.1 & -1.4 & -0.7 & -0.2 & 0.8 & 3.4 & 8.0 \\
\hline & 9 & -0.1 & -1.2 & -0.7 & -0.1 & 0.9 & 3.5 & 8.0 \\
\hline & 12 & -0.1 & -0.6 & -0.4 & -0.1 & 0.3 & 1.5 & 4.4 \\
\hline Income & 1 & -0.1 & -0.2 & 1.6 & 3.2 & 3.1 & 3.5 & 6.0 \\
\hline \multirow[t]{4}{*}{$\operatorname{Tax}$} & 3 & -1.4 & -1.5 & -0.1 & 1.5 & 1.7 & 3.3 & 7.3 \\
\hline & 6 & -1.3 & -2.1 & -0.7 & 0.7 & 1.1 & 3.2 & 8.0 \\
\hline & 9 & -1.2 & -2.4 & -1.0 & 0.3 & 0.8 & 3.1 & 8.0 \\
\hline & 12 & -1.7 & -3.6 & -3.6 & -3.0 & -2.5 & -0.2 & 4.4 \\
\hline Consumption & 1 & 0.7 & -2.1 & -0.6 & 0.5 & 1.3 & 3.2 & 6.0 \\
\hline \multirow[t]{4}{*}{$\operatorname{Tax}$} & 3 & -0.4 & -2.0 & 0.0 & 1.2 & 2.1 & 4.2 & 7.3 \\
\hline & 6 & -0.9 & -1.7 & 0.4 & 1.6 & 2.6 & 4.8 & 8.0 \\
\hline & 9 & -1.2 & -1.6 & 0.5 & 1.7 & 2.7 & 4.9 & 8.0 \\
\hline & 12 & -15 & -25 & -18 & -10 & -03 & 17 & 44 \\
\hline
\end{tabular}

Privatization with Flat Minimum Benefit

\begin{tabular}{llrrrrrrr}
\hline Payroll & 1 & 0.0 & -0.1 & 0.0 & 0.3 & 0.8 & 1.9 & 4.0 \\
Tax & 3 & -0.1 & -0.7 & -0.4 & -0.1 & 0.4 & 1.7 & 4.2 \\
& 6 & -0.1 & -0.8 & -0.5 & -0.2 & 0.3 & 1.7 & 4.3 \\
& 9 & -0.1 & -0.9 & -0.6 & -0.2 & 0.3 & 1.6 & 4.3 \\
& 12 & -0.1 & -0.5 & -0.4 & -0.2 & 0.0 & 0.6 & 2.3 \\
\hline Income & 1 & -0.1 & 1.8 & 3.1 & 4.3 & 4.1 & 4.2 & 5.7 \\
Tax & 3 & -1.4 & -0.5 & 0.6 & 1.7 & 1.7 & 2.3 & 4.8 \\
& 6 & -1.3 & -1.6 & -0.5 & 0.6 & 0.5 & 1.4 & 4.4 \\
& 9 & -1.2 & -2.1 & -1.0 & 0.0 & -0.1 & 1.0 & 4.1 \\
& 12 & -1.7 & -3.6 & -3.9 & -3.4 & -3.5 & -3.4 & 0.5 \\
\hline Consumption & 1 & 0.7 & -0.3 & 0.8 & 1.4 & 2.0 & 3.2 & 4.9 \\
Tax & 3 & -0.4 & -1.2 & 0.6 & 1.5 & 2.1 & 3.4 & 5.2 \\
& 6 & -0.9 & -1.3 & 0.6 & 1.6 & 2.2 & 3.5 & 5.4 \\
& 9 & -1.2 & -1.3 & 0.6 & 1.6 & 2.2 & 3.5 & 5.4 \\
& 12 & -1.5 & -25 & -19 & -12 & -07 & 0.5 & 20 \\
\hline \hline
\end{tabular}


Table 2 (continued)

\begin{tabular}{llrrrrrrr}
\hline \multicolumn{7}{c}{ Privatization } & with Progressive Matching \\
\hline Payroll & 1 & 0.0 & -1.0 & 0.4 & 1.6 & 2.2 & 4.2 & 8.0 \\
Tax & 3 & -0.5 & -1.3 & -0.2 & 0.9 & 1.6 & 4.0 & 8.4 \\
& 6 & -0.4 & -1.6 & -1.0 & 0.0 & 0.9 & 3.3 & 8.1 \\
& 9 & -0.4 & -1.8 & -1.4 & -0.6 & 0.3 & 2.9 & 7.7 \\
& 12 & -0.5 & -1.7 & -1.5 & -1.2 & -0.9 & 0.3 & 3.5 \\
\hline Income & 1 & -0.2 & 0.9 & 3.2 & 5.3 & 5.0 & 5.3 & 8.0 \\
Tax & 3 & -1.8 & -1.3 & 0.7 & 2.6 & 2.7 & 4.2 & 8.4 \\
& 6 & -1.6 & -2.4 & -1.0 & 0.7 & 0.9 & 2.9 & 8.1 \\
& 9 & -1.6 & -3.2 & -1.8 & -0.4 & -0.1 & 2.2 & 7.7 \\
& 12 & -2.1 & -4.9 & -5.0 & -4.3 & -4.1 & -1.7 & 3.5 \\
\hline Consumption & 1 & 0.9 & -1.6 & 0.5 & 1.9 & 2.8 & 4.7 & 7.6 \\
Tax & 3 & -0.5 & -1.8 & 0.7 & 2.3 & 3.2 & 5.4 & 8.5 \\
& 6 & -1.1 & -1.9 & 0.4 & 1.9 & 3.1 & 5.1 & 8.4 \\
& 9 & -1.5 & -2.0 & 0.2 & 1.7 & 2.7 & 4.9 & 8.1 \\
& 12 & -1.8 & -32 & -2.4 & -16 & -07 & 12 & 4.0 \\
\hline \hline
\end{tabular}

Notes: 1: bottom 2 percent, 3 : second decile, 6 : fifth decile, 9: eighth decile, 12: top 2 percent of the lifetime income distribution. 